\title{
Genetic Variability of Guzerat and Senepol Bovine Breeds by Microsatellite Markers
}

\author{
Ednaldo da Silva Filho ${ }^{1, *}$, Yasmin Martins dos Santos ${ }^{1}$, Yvana Melyssa Mandú \\ Margarido', Telmo José Mendes ${ }^{2}$, Luiz Marcelo de Lima Pinheiro ${ }^{3}$, Paulo Henrique de \\ Souza $^{1}$, José Elivalto Guimarães Campelo ${ }^{4}$
}

\begin{abstract}
Bovine production plays economic importance in Brazil and Guzerat and Senepol breeds are producer of meat. It was aimed to analyze the genetic variability of Guzerat and Senepol breeds by microsatellite markers. The breeds were collected and genotyped for ten microsatellite loci by automatic sequencer and statistically analysed. A total of 53 alleles were observed being the average number was 5.3 in both breeds. The effective numbers of alleles were 3.36 for Guzerat and 3.11 for Senepol cattle. The Shannon indexes were 1.36 for Guzerat and 1.26 for Senepol cattle. The expected heterozigosity were 0.71 and PIC values were 0.64 in both breeds. The F $F_{I S}$ were 0.01 and 0.11 for Guzerat and Senepol breeds, respectively and Hardy-Weinberg equilibrium were P>0.05 for Guzerat and $P<0.05$ for Senepol cattle. The combined discrimination powers were 0.99 in both breeds and combined exclusion powers (PE1) were 0.99 in both breeds and combined exclusion powers (PE2) were 0.96 and 0.95 for Guzerat and Senepol breeds respectively. There is genetic variability in both breed, but there are evidences of inbreeding enabling genetic drift and should be necessary to use major number of microsatellite loci to analyze with high efficiency the exclusion power (PE2).
\end{abstract}

KEYWORDS:Cattle, STRs, Diversity, Livestock conservation.

\section{Variabilidade Genética de Bovinos das Raças Guzerá e Senepol por Marcadores Microssatélites}

\begin{abstract}
RESUMO
A bovinocultura desempenha função importante na economia Brasileira e as raças Guzerá e Senepol são produtoras de carne. Objetivou-se analisar as variabilidades genéticas das raças Guzerá e Senepol através dos marcadores microssatélites. Os animais foram coletados e genotipados para dez loci microssatélites em um sequenciador automático de DNA e analisado estatisticamente. Um total de 53 alelos foi observado com número médio de 3,36 para Guzerá e 3,11 para a raça Senepol. Os índices de Shannon foram 1,36 para Guzerá e 1,26 para raça Senepol. As heteroziosidades esperadas foram $0,71 \mathrm{e}$ os valores de PIC foram 0,64 em ambas as raças. Os valores de $\mathrm{F}_{\mathrm{IS}}$ foram 0,01 e 0,11 para Guzerá e Senepol, respectivamente e as proporções de Hardy-Weinberg foram não significativas em Guzerá $(\mathrm{P}>0,05)$ e significativas em Senepol $(\mathrm{P}<0,05)$. Os poderes de discriminação combinados foram $0,99 \mathrm{em}$ ambas as raças e os poderes de exclusões combinados (PE1) foram 0,99 em ambas as raças e os poderes de exclusão combinados (PE2) foram 0,96 e 0,95 em Guzerá e Senepol, respectivamente. Existe variabilidade genética em ambas as raças, mas existem evidências de endocruzamentos por consequência da deriva genética e seria necessário avaliar um maior número de loci microssatélites para aumentar a eficiência no poder de exclusão (PE2).

PALAVRAS-CHAVE: Gado, STRs, Diversidade, Conservação animal.

*Author for correspondence.

${ }^{1}$ Federal Rural University of Amazon, Zip Code 66.077-901,Belém-PA, Brazil, silva.filho@ufra.edu.br.

${ }^{2}$ Federal University of Maranhão, Zip Code 65.500-000, Chapadinha-MA, Brazil.

${ }^{3}$ Federal University of Pará, Zip Code 68.800-000, Breves-PA, Brazil.

${ }^{4}$ Federal University of Piauí, Zip Code 64.049-550, Teresina-PI, Brazil.
\end{abstract}




\section{INTRODUCTION}

Bovine livestock in Brazil is a factor of the great economy importance, principally the beef cattle. Thus, Brazil is the country that has a biggest production of bovine livestock in the world. The official number of bovines that has been registered in Brazil by "Pesquisa da Pecuária Municipal" of "InstitutoBrasileiro deGeografia e Estatística" (IBGE, 2011) is about 212 million of animals. This number is considering animals used for both meat and dairy production.

Genetic variability of resources it is, actually, a world preoccupation to future for next generations, principally for genetic resources which serve as a food, both animal and vegetable origin. Moreover, the importance to maintain the genetic background as genetic variability source may to contribute with preservations of breeds and in improvement animal programs (Silva Filho et al., 2007).

With advancement of molecular biology has been very importance to study the genetic variability, through many tools. Thus, several studies about genetic variability in Brazilian bovines were made using differences tools, from RAPD (Serrano et al., 2004) to microsatellite markers (Egito et al., 2007). Actually, many papers are being published in differences sciences journals disseminating the current genetic structure of some Brazilian bovine breeds using Microsatellites markers (Carneiro et al., 2007).

Microsatellite DNA is a class within of the repetitive sequences of DNA in eukaryote genome and it is better known among markers. They are sequences of genome that consist of repeats from one to nine nucleotides in many copies in tanden found in vertebrates, insects, fungi and vegetables (Charlesworth et al., 1994). Historically, the microsatellite term is applied in repetitions with two nucleotides (CA) and (GT) and various others names are used to describe these repetitive sequences in tanden as Simple Sequence Repeat (SSRs) or Short Tanden Repeat (STRs) (Edwards et al., 1991).

Recently, microsatellites markers are being applied a lot in conservations studies of various organisms, from vegetable to animals. There are several advantage to use the microsatellite markers in detriment others molecular markers. Initially, microsatellites were applied in mapping genomic project (Weissenbach et al., 1992). It has been extensively used in association analyses of genes to disease susceptive (Rubinsztein 1999) and demonstrated extreme efficiency in paternity analyses of individuals (Edwards et al., 1992) and populations studies (Paetkau et al., 1995). Variation in microsatellite is used in hybridizations studies between correlated species (Roy et al., 1994). Therefore, it was aimed to analyze the genetic variability of two bovine breeds produced in Brazil, Senepol and Guzerat breeds, being a taurine and a zebuine respectively, utilizing microsatellite markers used in paternity exams routine recommend by International Society of Animal Genetics (ISAG).

\section{MATERIALS AND METHODS}

A total of 58 animals were casually selected from two differences Brazilian herd, being 29 animals of Senepol breed (Taurine) from a farm in Uberlândia town of Minas Gerais State and 29 animals of Guzerat breed (Zebuine) from a farm in Imperatriz town of Maranhão State. There were collected $5 \mathrm{~mL}$ of blood tissue by vacutainer blood collection and after they were conserved on freezer at $20^{\circ} \mathrm{C}$ to extraction of DNA. Extraction of DNA was realized by Phenol:Chloroform:Isoamyl Alcohol (25:24:1) method Sambrook et al., (1989). A set of ten loci of microsatellite markers were selected from loci used to paternity exam routine in bovine recommended by International Society of Animal Genetics (ISAG): BM1818, BM1824, BM2113, ETH10, ETH225, ETH3, INRA023, SPS115, TGLA122 and TGLA126 loci.

PCR reactions were realized in Multiplex System for a final volume of $15 \mu \mathrm{L}$ under the following conditions: Promega's STR 10X 
Buffer (1X); $\quad \mathrm{MgCl}_{2} \quad(1.5 \mathrm{mmol})$; every forward primer were marked using fluorescent dyes (FAM, HEX or TAMRA) (14 pmol) and reverse primer unlabeled (1-4 pmol); Platinum Taq DNA polymerase $\AA$ (Invitrogen, USA) (0.5 unit) and genomic DNA $(100 \mathrm{ng} / \mu \mathrm{L})$. PCR reactions were in a Mastercycler PCR Thermocycler (Eppendorf, Germany) under the following conditions: hot start at $94^{\circ} \mathrm{C}$ for $4 \mathrm{~min} ; 30$ cycles of $94^{\circ} \mathrm{C}$ for $1 \mathrm{~min}, 58^{\circ} \mathrm{C}$ for $1 \mathrm{~min}$ and $72^{\circ} \mathrm{C}$ for $1 \mathrm{~min}$; final extension temperature at $72^{\circ} \mathrm{C}$ for $4 \mathrm{~min}$. Products of PCR were separated and detected in the ABI Prism ${ }^{\circledR} 3100$ Genetic Analyzer (Applied Biosystems) following the manufacturer's standard protocol. Data was analyzed with GeneScan ${ }^{\circledR} \quad$ v3.7 and Genotyper ${ }^{\circledR} \quad$ v3.7 software (Applied Biosystems).

POPGENE 1.32 software (Yeh et al., 1999) was used to determine the allelic frequencies per locus as well as some diversity indexes as: Number of observed alleles $(\mathrm{Na})$ per locus; number of effective alleles ( $\mathrm{Ne}$ ) per locus and Shannon index $(S I)$. Expected heterozygosity (He) per locus was estimated according to Ney and Roychoudhury (1974). Polymorphism Informative Contend (PIC) was estimated according to Botstein et al. (1980).

A exact test was used to determine possible deviations of Hardy-Weinberg equilibrium (HWE) and existence of random associations of genotypes applying Markovian Chain method as well as it was determined the inbreeding coefficient $\left(F_{I S}\right)$ (Weir and Cocker,
1984) within of each population using GENEPOP 3.1d software (Raymond and Rousset, 1995).

Power of discrimination (PD) per locus was estimated according to Kloosterman et al. (1993). Probability of exclusion (PE) was determined in two situations: (PEl), estimated by 1 a equation, when the genotypes of matrix, offspring and bull are compared, this equation is appropriated when the matrix is confirmed as genitor at time of birth and (PE2), estimated by 2a equation, when at least one parental genotype not available (Jamieson and Taylor, 1997). Values per locus of $P D$, $P E 1$ and $P E 2$ were combined $(P D c$ and $P E c)$ to all loci evaluated ( $k$ loci) according to Fisher (1951).

\section{RESULTS AND DISCUSSION}

A total of 53 alleles were observed for ten loci analyzed in both breeds. However, the less polymorphism loci were BM1824 and INRA23, in the Guzerat and Senepol breeds, respectively, while the most polymorphism loci were BM1818 in Guzerat breed and BM2113 and TGLA126 in Senepol breed. The average proportion of effective allele in relation to observed allele was about 0.60 in the two breeds. Therefore, TGLA126 locus was the great proportion of effective allele in relation to observed allele (0.87) in Guzerat breed, while BM1818 (0.77) and BM1824 (0.77) loci were in Senepol breed (Tab. 1 and 2).

Table 1. Parameters of diversity in Guzerat breed.

\begin{tabular}{lccccccc}
\hline \multicolumn{1}{c}{ Loci } & $N a^{\mathrm{a}}$ & $N e^{\mathrm{b}}$ & $S I^{\mathrm{c}}$ & $H e^{\mathrm{d}}$ & $P I C^{\mathrm{e}}$ & Fis $^{\mathrm{f}}$ & $\mathrm{PHWE^{ \textrm {g } }}$ \\
\hline BM1818 & 7 & 3.68 & 1.57 & 0.75 & 0.70 & 0.25 & 0.07 \\
BM1824 & 3 & 2.16 & 0.91 & 0.56 & 0.48 & -0.05 & 1.00 \\
BM2113 & 6 & 4.75 & 1.65 & 0.82 & 0.76 & 0.02 & 0.88 \\
ETH10 & 5 & 2.59 & 1.17 & 0.64 & 0.56 & -0.05 & 0.15 \\
ETH225 & 6 & 4.00 & 1.56 & 0.78 & 0.72 & -0.01 & 0.48 \\
ETH3 & 5 & 3.40 & 1.36 & 0.73 & 0.65 & 0.09 & 0.92 \\
INRA23 & 6 & 2.07 & 1.08 & 0.53 & 0.49 & -0.01 & 0.11 \\
SPS115 & 5 & 3.86 & 1.41 & 0.77 & 0.69 & -0.13 & 0.81 \\
TGLA122 & 6 & 3.64 & 1.54 & 0.75 & 0.70 & 0.06 & 0.51
\end{tabular}




\begin{tabular}{lccccccc} 
TGLA126 & 4 & 3.48 & 1.30 & 0.74 & 0.66 & -0.10 & 0.44 \\
Average & 5.30 & 3.36 & 1.36 & 0.71 & 0.64 & 0.01 & $0.25^{\mathrm{i}}$ \\
Sd $^{\mathrm{h}}$ & 1.16 & 0.85 & 0.24 & 0.10 & 0.10 & 0.11 & \\
\hline
\end{tabular}

${ }^{\mathrm{a}}$ Number of observed alleles, ${ }^{\mathrm{b}}$ number of effective alleles, ${ }^{\mathrm{c}}$ Shannon index, ${ }^{\mathrm{d}}$ expectedheterozigosity, ${ }^{\mathrm{e}}$ polymorphism informative contend, ${ }^{\mathrm{f}}$ deficit of heteroziosity, ${ }^{\mathrm{g}}$ Probability for Hardy-Weinberg equilibrium, ${ }^{\mathrm{h}}$ standard deviation and iprobability for all loci.

Table 2. Parameters of diversity in Senepol breed.

\begin{tabular}{lccccccc}
\hline \multicolumn{1}{c}{ Loci } & $N a^{\mathrm{a}}$ & $N e^{\mathrm{b}}$ & $S I^{\mathrm{c}}$ & $H e^{\mathrm{d}}$ & $P I C^{\mathrm{e}}$ & $F_{i s^{\mathrm{f}}}$ & $\mathrm{PHWE^{ \textrm {g } }}$ \\
\hline BM1818 & 5 & 3.84 & 1.45 & 0.76 & 0.69 & 0.27 & 0.04 \\
BM1824 & 4 & 2.18 & 0.96 & 0.56 & 0.49 & 0.62 & 039 \\
BM2113 & 7 & 5.22 & 1.73 & 0.84 & 0.78 & -0.13 & 0.26 \\
ETH10 & 5 & 3.83 & 1.47 & 0.77 & 0.70 & -0.01 & 0.26 \\
ETH225 & 5 & 2.16 & 1.10 & 0.55 & 0.50 & 0.31 & 0.00 \\
ETH3 & 5 & 3.37 & 1.33 & 0.73 & 0.66 & -0.26 & 0.04 \\
INRA23 & 3 & 1.42 & 0.57 & 0.32 & 0.29 & 0.33 & 0.02 \\
SPS115 & 6 & 2.57 & 1.21 & 0.64 & 0.58 & 0.00 & 0.55 \\
TGLA122 & 6 & 3.05 & 1.31 & 0.69 & 0.61 & -0.16 & 0.70 \\
TGLA126 & 7 & 3.48 & 1.46 & 0.74 & 0.67 & 0.10 & 0.37 \\
Average & 5.30 & 3.11 & 1.26 & 0.71 & 0.64 & 0.11 & $0.00^{\mathrm{i}}$ \\
Sd & 1.25 & 1.08 & 0.32 & 0.15 & 0.14 & 0.27 & \\
\hline
\end{tabular}

${ }^{a}$ Number of observed alleles, ${ }^{b}$ number of effective alleles, ${ }^{c}$ Shannon index, ${ }^{d}$ expectedheterozigosity, ${ }^{\text {e }}$ polymorphism informative contend, ${ }^{\mathrm{f}}$ deficit of heteroziosity, ${ }^{\mathrm{g}}$ Probability for Hardy-Weinberg equilibrium, ${ }^{\mathrm{h}}$ standard deviation and iprobability for all loci.

Average Shannon index $(S I)$ were over 1 in the two breeds. The expected heterozygosity varied from 0.53 to 0.82 in Guzerat breed, while Senepol breed varied from 0.32 to 0.84 and the average heterozygosity were over 0.70 in two breeds. The values of PIC varied from 0.48 to 0.76 in Guzerat breed, while Senepol varied from 0.29 to 0.78 and the average heterozygosis were over 0.60 in both breeds (Tab. 1 and 2).

The inbreeding coefficients $\left(F_{I S}\right)$ varied from 0.10 to 0.25 in Guzerat breed, while Senepol breed varied from -0.26 to 0.62 . All breeds had positive average heterozygosis deficit indicating presence of consanguine breeding. Nothing locus had significant $(\mathrm{P}>0.05)$ deviation from HW equilibrium in Guzerat breed, while Senepol breed had some loci with significantdeviations from HWE (P $<0.05$ ) (Tab. 1 and 2).

The values of $P D$ parameter varied from 0.70 to 0.90 and combined of 0.99 in Guzerat breed, while Senepol breed varied from 0.43 to 0.89 and combined of 0.99 . The $P E 1$ values varied from 0.28 to 0.58 and combined of 0.99 in Guzerat breed, while Senepol breed varied from 0.16 to 0.62 and with combined of 0.99 . The $P E 2$ values varied from 0.14 to 0.35 and with combined of 0.96 , while Senepol breed varied from 0.05 to 0.45 and combined of 0.95 (Tab. 3).

Table 3. Analyses of discrimination and exclusion powers.

\begin{tabular}{lcccccc}
\hline \multirow{2}{*}{ Loci } & \multicolumn{3}{c}{ Guzerat breed } & \multicolumn{3}{c}{ Senepol breed } \\
\cline { 2 - 7 } & PD & PE1 & PE2 & PD & PE1 & PE2 \\
\hline BM1818 & 0.81 & 0.52 & 0.33 & 0.87 & 0.50 & 0.33 \\
BM1824 & 0.72 & 0.28 & 0.14 & 0.72 & 0.30 & 0.15 \\
BM2113 & 0.90 & 0.58 & 0.41 & 0.89 & 0.62 & 0.45 \\
ETH10 & 0.74 & 0.36 & 0.20 & 0.87 & 0.52 & 0.34 \\
\hline
\end{tabular}




\begin{tabular}{lllllll} 
ETH225 & 0.80 & 0.53 & 0.35 & 0.66 & 0.33 & 0.16 \\
ETH3 & 0.87 & 0.45 & 0.28 & 0.78 & 0.46 & 0.29 \\
INRA23 & 0.70 & 0.32 & 0.15 & 0.43 & 0.16 & 0.05 \\
SPS115 & 0.86 & 0.49 & 0.32 & 0.79 & 0.39 & 0.22 \\
TGLA122 & 0.87 & 0.52 & 0.33 & 0.80 & 0.42 & 0.26 \\
TGLA126 & 0.83 & 0.45 & 0.28 & 0.85 & 0.48 & 0.31 \\
Combined & 0.99 & 0.99 & 0.96 & 0.99 & 0.99 & 0.95 \\
\hline
\end{tabular}

Comparing the polymorphism with those observed in some European breeds (Kantanem et al., 2000), they were very similar and compared with Brazilian breeds as: Nelore that was more polymorphic than this work (Cevini et al., 2006; Carneiro et al., 2007). O SI indicated high genetic variability (over 1.0) as affirmed by Fatima et al. (2008) evaluating goats breeds and by Arif et al. (2010) evaluating antelope breeds using microsatellite markers. Average expected heterozigosities and average PIC indicated high genetic variability in both breeds as compared with the taurine and zebuine breeds created in Brazil, including the Guzerat breed (Egito et al., 2007). Same conditions were observed by Carneiro et al. (2007) analyzing Nelore breed on Amazon conditions. The deficits of heterozigosity were literally same those observed in some breeds as Hariana and Hissar (Rehman and Khan, 2009), Brown Swiss breed (Dalvit et al., 2008), Hallikar cattle (Shekar et al., 2011) and taurine and zebuine breeds from Brazil (Egito et al., 2007). Therefore, some breeds were not observed deficits of heterozigosity as Kangayam cattle (Karthickeyan et al., 2009) and Burlina and Hostein Frisian breeds (Davit et al., 2008). Although all loci have showed considered variability, they were viable for analyses of discriminations as those observed in the Nelore breed (Carneiro et al., 2007) and Yugoslav Pied cattle (Stevanovic et al., 2010), but should be necessary to extend the number of loci to have more efficiency in paternity analyses (Silva Filho et al., 2007).

\section{CONCLUSION}

All breeds analyzed indicated considerable genetic variability using 11 microsatellite loci, but the deficit of heterozigosity may be due to consanguine breeding within each breed being necessary the use of molecular markers assisted selection (MAS) by animal improvement program and to use more microsatellite loci in these breeds for better efficiency in paternity analyses.

\section{ACKNOWLEDGMENTS}

We thank all the owners of the farms that kindly gave samples of the two breeds.

\section{REFERENCES}

ARIF, I.A.;KHAN, H.A.;SHOBRAK, M.;HOMAIDAN, A.A.;SADOON, M.A.;FARHAN, A.H. Measuring the genetic diversity of Arabian Oryx using microsatellite markers: implication for captive breeding. Genes \& Genetic Systems, v.85, p.141-145, 2010.

BOTSTEIN, D.; WHITE, R.L.; SKOLNICK, M.; DAVIS, R.W. Construction of a genetic linkage map in man using restriction fragment length polymorphisms. American Journal of Human Genetics, v.32, p.314331,1980 .

CARNEIRO, T.X.; GONÇALVES, E.C.; SCHNEIDER, M.P.C.; SILVA, A. Diversidade genética e eficiência de DNA microssatélites para o controle genealógico da raça Nelore. Arquivo Brasileiro de Medicina Veterinária e Zootecnia, v.59, p.1257-1262, 2007.

CERVINI, M.; SILVA, H.F.; MORTARI, N.; MATHEUCCI, J.R.E. Geneticvariabilityof 10 microsatellitemarkers

thecharacterizationofBrazilianNellorecattle

(Bosindicus). Genetics and Molecular Biology, v.29, p.486-490, 2006.

CHARLESWORTH, B.; SNIEGOWSKI, P.; STEPHAN, W. The evolutionary dynamics of repetitive DNA in eukaryotes. Nature, v.371, p.215220, 1994. 
DALVIT, C.; DE MARCHI, M.; DAL ZOTTO, R.; ZANETTI, E.;MEUWISSEN, T.; CASSANDRO, M. Genetic characterization of the Burlina cattle breed using microsatellites markers. Journal of Animal Breeding and Genetics, v.125, p.137-144, 2008.

EDWARDS, A.;CIVITELLO, A.;HAMMOND, H.A.;CASKEY, C.T. DNA typing and genetic mapping with trimeric and tetrameric tandem repeats. American Journal of Human Genetics, v.49, p.746-756, 1991.

EDWARDS, A.; HAMMOND, H.A.; JIM, L. et al. Genetic variation at five trimeric and tetrameric tandem repeat loci in four human population groups. Genomics, v.12, p.241-253, 1992.

EGITO, A.A.; PAIVA, S.R.; ALBUQUERQUE, M.D.S.M.; MARIANTE, A.S.; ALMEIDA, L.D.; CASTRO, S.R.; GRATTAPAGLIA, D.Microsatellite based genetic diversity and relationships among ten Creole and commercial cattle breeds raised in Brazil. BMC Genetics, v.8, p.1-14, 2007.

FATIMA, S.;BHONG, C.D.;RANK, D.N.;JOSHI, C.G. Genetic variability and bottleneck studies in Zalawadi, Gohilwadi and Surti goat breeds of Gujarat (India) using microsatellites. Small Ruminant Research, v.77, p.58-64, 2008.

FISHER, R. Standard calculations for evaluating a blood group system. Heredity, v. 5, p. 95-102, 1951.

IBGE, Instituto Brasileiro de Geografia e Estatística. Produção da Pecuária Municipal, Rio de Janeiro, RJ, Brasil, v.39, 2011.63p.

JAMIESON, A.; TAYLOR, S.C. Comparisons of three probability formula for parentage exclusion. Animal Genetics, v.28, p.397-400, 1997.

KANTANEN, J., OLSAKER, I., HOLM, L.E.; LIEN, S.; VILKKI, J.; BRUSGAARD, K.; EYTHORSDOTTIR, E.; DANELL, B.; ADALSTEINSSON, S. Genetic diversity and population structure of 20 north European cattle breeds. The Journal of Heredity, v.91, p.446-457, 2000.

KARTHICKEYAN, S.M.K.; SIVASELVAM, S.N.; SELVAM, R.; THANGARAJU, P. Microsatellite analysis of Kangayam cattle (Bosindicus) of Tamilnadu.Indian Journal of Science and Technology, v.2, p.38-40, 2009.

KLOOSTERMAN, A.D.; BUDOWLE, B.; DASELAAR, P. PCR-amplification and detection of the human D1S80 VNTR locus, Amplification conditions, population genetics and application in forensic analysis. International Journal of Legal Medicine, v.7, p.257-264, 1993.

NEY, M.; ROYCHOUDHURY, A.K. Sampling variances of heterozygosity and genetic distance. Genetics, v.76, p.379-390, 1974.

PAETKAU, D.; CALVERT, W.; STIRLING, I.; STROBECK, C. Microsatellite analysis of population structure in Canadian polar bears. Molecular Ecology, v.4, p.347-354, 1995.

RAYMOND, M.; ROUSSET, F. GENEPOP (Version 1.2): Population Genetics Software for Exact Tests and Ecumenicism. Journal of Heredity, v.86, p.248-249, 1995.

REHMAN, M.S.; KHAN, M.S. Genetic diversity of hariana and hissar cattle from pakistan using microsatellite analysis. Pakistan Veterinary Journal, 29, 67-71, 2009.

ROY, M.S., GEFFEN, E., SMITH, D.; OSTRANDER, E.A.; WAYNE, R.K.Patterns of differentiation and hybridization in North American wolflikecanids, revealed by analysis of microsatellite loci.Molecular Biology and Evolution, v.11, p.553-570, 1994.

RUBINSZTEIN, D.C. Trinucleotide expansion mutations cause diseases which do not conform to classical Mendelian expectations. In: Goldstein, D.B.;Schlötterer, C. (eds) Microsatellites: evolution and applications. Oxford University Press, 1999, pp 80-97.

SAMBROOK, J.; FRITSCH, E.F.; MANIATIS, T. Molecular Cloning. In A Laboratory Manual. Cold Spring Harbor Laboratory Press. New York, v. 1, 2 and 3. 1989.

SERRANO, G.M.; EGITO, A.A.; MCMANUS, C.; MARIANTE, A.S. Genetic diversity and population structure of Brazilian native bovine breeds. PesquisaAgropecuáriaBrasileira, v.39, p.543-549, 2004.

SHEKAR, M.C.; KUMARA, J.U.; KARTHICKEYAN, S.M.K.; MUTHEZHILAN, R. Assessment of with-in breed diversity in Hallikar cattle (Bosindicus) through microsatellite markers. IndianJournalof Science and Technology, v.4, p.895898, 2011.

SILVA FILHO, E.; SCHNEIDER, M.P.C.; SILVA, A. Variabilidade Genética de Cavalos baseada em DNA Microssatélites. RevistaTrópica: CiênciasAgrárias eBiológicas, v.1, p.76-87, 2007. 
STEVANOVIC, J.; STANIMIROVIC, Z; DIMITRIJEVIC, V.; MALETIC, M. Evaluation of 11 microsatellite loci for their use in paternity testing in Yugoslav Pied cattle (YU Simmental cattle).Czech Journal of Animal Science, v.55, p.221-226, 2010.

WEIR, B.S.; COCKERHAM, C.C. Estimating FStatistics for the Analysis of Population Structure. Evolution, v.38, p.1358-1370, 1984.

WEISSENBACH, J., GYAPAY, G., DIB, C.; VIGNAL, A.; MORISSETTE, J.; MILLASSEAU, P.; VAYSSEIX, G.; LATHROP, M. A second-generation linkage map of the human genome. Nature, v.359, p.794-801, 1992.

YEH, F.; YANG, C.; BOYLE, T. POPGENE version 1.32 Microsoft window-based freeware for Population Genetic Analysis. University of Alberta. Edmonton, AB. Canada. 1999. 